\author{
К. М. Корчагин \\ Институт русского языка им. В. В. Виноградова РАН \\ (Россия, Москва) \\ stivendedal@gmail.com
}

\title{
ЦЕЗУРА В РУССКОМ 5-СТОПНОМ ЯМБЕ И ЕЕ РОЛЬ В РИТМИЧЕСКОЙ ЭВОЛЮЦИИ ЭТОГО РАЗМЕРА*
}

Русский 5-стопный ямб - один из самых распространенных и один из самых хорошо исследованных размеров. Исчерпывающе подробное описание его ритмики на материале XVIII-XIX вв. было сделано К. Тарановским еще в середине XX в. (Тарановский 2010), а затем дополнено М.Л. Гаспаровым (Гаспаров 1974; 2002). Тем не менее, в истории этого размера остаются «слепые зоны», связанные как с тем, что за время, прошедшее с упомянутых классических работ, были опубликованы важные тексты, проясняющие некоторые детали его эволюции, так и с тем, что подход классиков русского стиховедения предполагал детальное исследование профилей ударности, но почти игнорировал другие ритмические факты стиха, прежде всего цезуру. Отчасти это было связано с тем, что русское стиховедение 1960-1970-х гг. стремилось создать теорию метрики с чистого листа, подвергнуть ревизии все то, что составляло предмет старых руководств по поэтике и стихосложению. В этом оно было близко лингвистическому структурализму, хотя последний воспринимался скептически М. Л. Гаспаровым и его последователями.

Для того чтобы показать влияние этих несвоевременно отброшенных ритмических фактов на эволюцию 5-стопного ямба, я произведу частичную ревизию истории этого размера в том виде, в каком она изложена у К. Тарановского и М. Л. Гаспарова. Это позволит показать, что граница между классическими размерами (такими как 5-стопный ямб) и неклассическими (такими как дольник и тактовик) не должна восприниматься как непреодолимая: последние являются прямыми следствиями эволюции ритма первых. Однако это невозможно показать, если руководствоваться принятыми в русском стиховедении способами анализа ритмики стиха, стремящимися изолировать различные типы размеров, избегая вопроса

* Исследование выполнено при финансовой поддержке РФФИ в рамках научного проекта № 17-29-09154 «Динамика языковой системы: корпусное исследование синхронной вариативности и диахронических изменений в текстах разных типов». 
о том, как они могут быть связаны друг с другом. Для того чтобы сделать эту связь ясной, я вернусь к понятию цезуры как к ключевому для анализа стиха и попытаюсь показать, каким образом оно позволяет уточнить эволюцию русского 5-стопного ямба.

Ключевые слова: метрика, стиховедение, 5-стопный ямб, цезура, эволюция русского стиха, поэтический корпус, НКРЯ

У русского 5-стопного ямба было, как минимум, три зарубежных источника: французский vers commun (10-сложник $4+6)$, немецкий 5-стопный ямб и затем английский 5-стопный ямб ${ }^{1}$. Наиболее влиятельными эти образцы (особенно первый из них) были на ранних стадиях развития размера - начиная с определенного момента русский 5-стопный ямб начинает развиваться независимо, что непосредственно сказывается на интерпретации как цезуры, так и других элементов стиха. Во многом это связано с тем, что к XIX в. 10-сложник во французской поэзии практически выходит из употребления (Гаспаров 2003: 110), а немецкий и английский виды этого размера уже мало отличаются от русского в трактовке цезуры.

Для 5-стопного ямба важно различать два вида цезур, впервые в таком виде выделенных В.М. Жирмунским [Жирмунский 1975], а затем подробно проанализированных Дж. Бейли [Бейли 2004: 220-251]. Это слабая и сильная цезуры. В случае слабой цезуры речь идет только о регулярном словоразделе, который не сопровождается дополнительной метрической (ударной) константой. Напротив, сильная цезура - это регулярный словораздел, который таковой сопровождается. В истории русского стиха эти два типа цезур сменяют друг друга: если классическая силлабо-тоника XVIII-XIX вв. предпочитает слабую цезуру, то в XX в. в тех же размерах начинает использоваться сильная. По всей видимости, это было связано с тем, что стих с цезурой воспринимается как экзотика, и поэтам требуется дополнительное средство, чтобы привлечь внимание читателя к тому, что они не просто соблюдают классический размер, но используют его в наиболее строгом варианте - с цезурой.

В истории 5-стопного ямба цезура закрепляется отнюдь не сразу и держится очень недолго, хотя и оставляет после себя достаточно долгую память: до сих пор в практических руководствах по стихосложению 5-стопный ямб упоминается как

\footnotetext{
${ }^{1}$ Немецкий вариант существовал как в цезурном, так и в бесцезурном виде: первый воспринимался как аналог французского 10-сложника, второй - итальянского 11-сложника (Wagenknecht 2007: 86-87). Английский вариант в лучшем случае обладает лишь колометрической цезурой . Русский пятистопный ямб почти всегда бесцезурен. Однако тот факт, что бесцезурный 5-стопный ямб генетически восходит к 5-стопному ямбу с цезурой после второй стопы и часто сохраняет словораздел в этой позиции, заставляет некоторых исследователей говорить о свободной цезуре, если стихотворение содержит 80-95\% строк со словоразделом в обычной цезурной позиции (Тарановский 2010: 153; Бейли 2004: 182). Используемая в настоящей статье классификация цезур обходится без этого понятия, и стих такого типа в общем случае будет считаться либо бесцезурным, либо цезурным с отдельными отклонениями.
} 
цезурный размер, хотя количество его бесцезурных образцов в сотни и тысячи раз больше. На материале поэзии XVIII в. видно, что 5-стопный ямб не сразу закрепляется в метрическом репертуаре русской поэзии. В поэтическом подкорпусе НКРЯ обнаруживается всего девять образцов этого размера: они принадлежат В. Тредиаковскому (один образец, если не считать иллюстраций к стиховедческим работам), М. Ломоносову (переводы Горация и Марциала), А. Сумарокову, Я. Княжнину, П. Словцову и М. Муравьеву (последнему - целых шесть текстов, больше, чем у любого другого поэта эпохи). Все эти образцы в известном смысле маргинальны - они не формируют заметной традиции даже в рамках индивидуальных поэтик; только Муравьев писал этим размером более или менее систематически.

Тредиаковский определял 5-стопный ямб следующим образом: «Стих пентаметр ямбический имеет два полстишия, то есть он пресекается. В первом полстишии мужеского стиха содержит он две стопы, из сих последния есть пресечение, а во втором три стопы ровно» (Тредиаковский 2009: 80). За этим следует утверждение, что полустишие «никогда не долженствует пресекаемо быть пиррихием, но всегда и непременно ямбом» (Там же: 81). Впрочем, далее он говорит о допустимости 5-стопного ямба без цезуры («в самых малых шутках: сему я не советую в важном Сочинении подражать»). Другими словами, Тредиаковский использовал в 5-стопном ямбе сильную цезуру, хотя не настаивал на ее обязательности:

Приятный бре́г! || Любезная страна!

Где свой Нева́ $\|$ поток стремит к пучине.

O! прежде де́брь, || се коль населена!

Мы град в тебе́ $\|$ престольный видим ныне...

В. Тредиаковский, «Похвала Ижерской земле...», 1752

Следующий опыт сильной цезуры в этом размере обнаруживается у Сумарокова в VI идиллии, что может показаться неожиданным на фоне того, как по-разному понимали Тредиаковский и Сумароков цезуру в 6-стопном ямбе: первый настаивал на том, что она должна быть всегда сильной, второй же - что всегда слабой. Но в трактовке 5-стопного ямба эти непримиримые соперники совпали. Причина этого, по-видимому, в том, что 5-стопный ямб в то время воспринимался как размер периферийный, не требующий особо тщательной «русификации» и сохранявший некоторые особенности французского прототипа, 10 -сложника $4+6$, где цезура могла быть только сильной.

Действительно, 5-стопный ямб XVIII в. в основном ведет себя непоследовательно с точки зрения цезуры, хотя о каких-либо общих тенденциях трудно говорить в силу бедности материала. Так, в переводе небольшой эпиграммы Марциала, выполненном Ломоносовым для «Риторики» (1759), цезура не соблюдается:

О имя, купно с ро́||'зами рожденно!

Тобой зовется ле́||'та часть прекрасна. 
Ты сладко, как цветы' || и мед Иблейский

И как пресладкий не́к|"тар на Олимпе.

Тобою бы жела́л || назваться отрок,

Зевесов виночерпец.

Еще более интересный случай — перевод Ломоносова знаменитой оды Горация (III, 30) «Exegi monumentum aere perennius...» <1747>:

Я знак бессме́ртия || себе воздвигнул

Превыше пирами́д || и крепче меди,

Что бурный аквило́н \| сотреть не может,

Ни множество веко́в, || ни едка древность...

Здесь слабая цезура занимает позицию не после второй, а после третьей стопы (Тарановский 2010: 153). Эксперимент, однако, остался единичным в этой эпохе: разработка неклассических цезурных вариаций 5-стопного ямба возобновится лишь в XX в.

В 1770-1780-е гг. 5-стопный ямб периодически использует М. Муравьев (напомним, что образцов этого размера у него больше, чем у какого-либо другого поэта XVIII в.). У Муравьева употребляется цезура после второй стопы, но,в отличие от Тредиаковского и Сумарокова, она всегда слабая, что можно воспринимать как признак «русификации» размера, сближения его с русским александрийским стихом:

Това́рищи, || наставники, друзья,

Д.ц.

О книги! к ва́м \| украдываюсь я

М.ц.

Мгновенье скры́ть || оставшейся прохлады, .ц.

Вкушая в ва́с \| полезные отрады. м.ц.

И время те́чь \| скоряе обяжу... м.ц.

«Товарищи, наставники, друзья...», 1779

Среди 5-стопных ямбов Муравьева обнаруживается лишь одна строка (из 141-й, написанных этим размером), где позиция цезуры нарушается: Вошедша гос $\|^{?}$ тя зрят. Они мне святы («Итак, опять убежище готово...», 1780). В этих стихах Муравьева употребляется 26\% дактилических полустиший и 74 \% мужских. Речевая модель цезурного варианта этого размера, предложенная М. Л. Гаспаровым для поэзии XIX в., дает 35,9\% дактилических полустиший и 64,1\% мужских (Гаспаров 1974: 103), что заметно отличается от данных по Муравьеву. По всей видимости, для этого поэта было важно подчеркивать цезуру мужским окончанием именно в силу того, что размер еще не казался ему привычным и естественным.

За опытами Муравьева следует 5-стопный ямб Княжнина («Послание трем грациям», <1790>), где также используется слабая цезура: 
О не́жные || сестрицы неразлучны!

Сопу́тницы || прекрасного всего!

Сама краса́ || не стоит ничего,

Черты еé || бездушны, вялы, скучны,

Коль, ва́шего || знакомства лишена,

Жема́нится || без прелестей она...
д.Ц.

д.ц.

М.ц.

М.Ц.

д.Ц.

д.ц.

В этом послании дактилический цезурный словораздел встречается почти так же часто, как мужской, - 43,5\% дактилических полустиший и 56,5\% мужских (всего в стихотворении 139 строк, причем одна из них - 4-стопная).

Первые бесцезурные 5-стопники появляются в то же десятилетие - у П. Словцова в двух довольно длинных натурфилософских одах, опубликованных в 1796 г.: «К Сибири» и «Материя», почти на два десятилетия раньше, чем переводы Жуковского из Гебеля (1816), упоминаемые К. Тарановским в качестве первых образцов этого размера. Словцов происходил из семьи священника, он родился в горно-заводской части Сибири (ныне Свердловская область), учился в Тобольской духовной семинарии, а затем за успехи в обучении был отправлен в Петербург в Александро-Невскую семинарию, где его соучеником был М. М. Сперанский. Еще в ранние годы он был увлечен идеей «научной» поэзии и вдохновлен естественнонаучными опытами Ломоносова и его же «Письмом о пользе стекла». Авторское примечание к оде «Материя», сочиненной еще в семинарии, гласит: «Сочинитель сей пиесы хотел только испытать, можно ли физические истины предлагать в стихах» [Поэты 1790-1810-х гг. 1971: 212]. Два упомянутых стихотворения стилистически близки к торжественной оде XVIII в., но тематика их далека от тематики таких од. Возможно, именно это расхождение подтолкнуло поэта использовать необычный для оды и редкий в то время размер - бесцезурный 5-стопный ямб:

Дщерь Азии, богато наделенна!

По статным и дородным раменам

Бобровою порфирой облеченна,

С собольими хвостами по грудям,

Царевна! сребряный венец носяща

И пестрой насыпью камней блестяща!

Славян наперсница, орд грозных мать,

Сибирь - тебя мне любо вспоминать...

П. Словияов, «К Сибири», 1796

Словораздел после второй стопы встречается здесь всего в 36,8\% строк (из 136), то есть отсутствует даже минимальная тенденция к тому, чтобы сосредоточивать словоразделы после второй стопы ${ }^{2}$.

${ }^{2}$ Сходные показатели дает другой ранний пример бесцезурного 5-стопного ямба - драма В. Т. Нарежного «Кровавая ночь, или Конечное падение дому Кадмова» (1799). Строго говоря, эта 
Таким образом, можно считать, что в этот период 5-стопный ямб уже разделился на два варианта - цезурный и бесцезурный. Второй вариант быстро стал широко употребительным размером и сохранял эти позиции до самого последнего времени, превратившись, по сути, в наиболее популярный классический размер [Гаспаров 2002: 306-314]. История же цезурного 5-стопного ямба более прерывистая - в некоторые эпохи, особенно когда возрождается интерес к поэтической классике, он мог ненадолго входить в моду, в другие - почти совсем пропадать.

В первые десятилетия XIX в. цезурный 5-стопный ямб переживает кратковременный расцвет. В основном в поэзии этого периода употреблялся 5-стопный ямб со слабой цезурой (как у Муравьева и Княжнина); отступления от этой закономерности были очень редкими и нуждались в специальной мотивировке. Согласно данным К. Тарановского ${ }^{3}$, стремление к мужскому окончанию первого полустишия в 5-стопном ямбе у поэтов до 1840 г. выражено достаточно четко: больше всего мужских полустиший у Полежаева в 1834 г. (95,5\% - это почти ударная константа), меньше всего - у Батюшкова в 1817 г. (58,9\%; впрочем, сразу за ним, хотя и с большим разрывом, следует Баратынский с $67,3 \%$, близкий к речевой модели). Таким образом, количество мужских полустиший не опускается ниже речевой модели: дактилическое окончание ни у кого, кроме Батюшкова, сознательно не выводится на первый план. Если усреднить все показатели, предварительно изъяв из списка Батюшкова с его резко индивидуальной ритмикой, то для всего периода получится $22,4 \%$ дактилических полустиший и 78,6\% мужских. Другими словами, тенденции, обнаруживаемые в стихах Муравьева, становятся в первой половине XIX в. еще более заметными: предцезурное полустишие гораздо чаще несет мужское, а не дактилическое окончание - в случае, когда используется цезурный вариант размера, требуется дополнительно подчеркнуть это ритмическими средствами.

Сильную цезуру в 5-стопном ямбе использует, например, Жуковский в переводе песни Миньоны из романа Гёте «Годы учения Вильгельма Мейстера» (под названием «Мина», 1817) и в «Верности до гроба» (переложение Теодора Кернера, 1818) [Тарановский 2010: 170-174]:

Я знаю кра́й! || там негой дышит лес,

Златой лимо́н || горит во мгле древес,

И ветеро́к || жар неба холодит,

И тихо ми́рт $\|$ и гордо лавр стоит...

Там счастье, дру́г! туда! туда

Мечта зове́т! || Там сердцем я всегда!

«Мна», 1817

драма написана вольным ямбом, но 5-стопные строки в ней преобладают $(88,4 \%)$. О стихе этой драмы см. подробнее в: [Бейли 2004: 104-108].

${ }^{3}$ В этих расчетах были учтены: И. Крылов, В. Жуковский, П. Вяземский, К. Батюшков, А. Пушкин, А. Дельвиг, П. Плетнев, И. Козлов, Н. Языков, Е. Баратынский, С. Шевырев, А. Подолинский, А. Полежаев, В. Одоевский. Данные по ударности 5-стопного ямба для всех этих поэтов почти не отличаются с точки зрения предцезурной позиции. 
Младой Роге́р || свой острый меч берет,

За веру, че́сть $\|$ и родину сразиться.

Готов он в бо́й... || но к милой он идет,

В последний ра́з $\|$ с прекрасною проститься...

«Верность до гроба», 1818

В «Мине» пятая строка каждой строфы 4-стопная и сохраняется словораздел после второй стопы. В немецком оригинале песни Миньоны также используется 5-стопный ямб с сильной цезурой, но с единичным смещением словораздела на слог вправо. Стихотворение же Кернера устроено несколько иначе: в нем катрены 5-стопного ямба чередуются с катренами 4-стопного ямба, причем позиция цезуры иногда нарушается:

Kennst du das Háus? \| Auf Säulen ruht sein Dach.

Es glänzt der Sáal, $\|$ es schimmert das Gemach,

Und Marmorbíl||'der stehn und sehn mich an:

Was hat man dir, du armes Kind, getan?-

Kennst du es wohl?

$$
\text { Dahin, dahin }
$$

Möcht ich mit dír, || o mein Beschützer, ziehn!

J.W. Goethe, «Mignon», 1795

Der Ritter múß || zum blut'gen Kampf hinaus,

Für Freiheit, Rúhm || und Vaterland zu streiten;

Da zieht er nóch $\|$ vor seines Liebchens Haus,

Nicht ohne $A b \|$ 'schied will er von ihr scheiden.

T. Kerner, «TreuerTod», <1813>

Важно, что цезурный вариант 5-стопного ямба в немецком стихе почти не употреблялся, так что приведенные стихотворения Гёте и Кернера в известном смысле исключения, демонстрирующие встречное влияние французского десятисложника, всегда содержащего цезуру [Тарановский 2010: 174]. Связанный с этим фактом эпизод в истории размера - полемический обмен колкостями между Жуковским и Пушкиным:

Послушай, дедушка, мне каждый раз,

Когда взгляну на этот замок Ретлер,

Приходит в мысль, что, если это проза,

Да и дурная?.....

$$
<1818>
$$

Эти строки Пушкина пародируют начало длинного драматического стихотворения Жуковского «Тленность» (1816), перевода стихотворения Гебеля «Die 
Vergänglichkeit». Обычно считается, что Пушкин в этой эпиграмме метит в использованный старшим товарищем белый стих, однако такое прочтение может показаться странным на фоне того, что сам Пушкин впоследствии неоднократно писал белым стихом. Можно предположить, что предмет полемики иной - отсутствие цезуры в размере, избранном Жуковским. Действительно, все 5-стопные ямбы молодого Пушкина содержат цезуру, в том числе и белые ямбы драмы «Борис Годунов» (1825), что отнюдь не тривиально для драматического белого стиха, который в дальнейшей истории русской поэзии избегает цезуры так же, как и его английский прототип. Так, драматическая трилогия А.К. Толстого (1866-1870), непосредственно ориентировавшегося на «Бориса Годунова», уже бесцезурна ${ }^{4}$. В черновике предисловия к драме Пушкин писал: «Я сохранил цезурку французского пентаметра на второй стопе - и, кажется, в том ошибся, лишив добровольно свой стих свойственного ему разнообразия» (цит. по: [Тарановский 2010: 216]).

5-стопный ямб с цезурой утрачивает популярность в 1840-1850-е гг., когда его окончательно вытесняет бесцезурный стих. Это также связано с Пушкиным, который начинает активно пользоваться бесцезурным ямбом в 1830-е гг. — когда его практика уже становится знаковой для большинства поэтов. И первое же вступление на поле бесцезурного ямба, поэма «Домик в Коломне» (1830), может быть названа образцом для всех дальнейших опытов в этом роде - как и у самого Пушкина, который далее пишет этим размером и лирику, и «Маленькие трагедии», так и у его современников. Пример оказался настолько заразителен, что среди заметных поэтов послепушкинского времени цезурный вариант используют только немногочисленные одиночки - А. Майков, К. Павлова и И. Никитин: их средние показатели - 23,9\% дактилических полустиший и 76,1\% мужских. Таким образом, уже в это время 5-стопный ямб с цезурой становится размером, который любят одни поэты и игнорируют другие, причем первых, как правило, немного.

В цезурном 5-стопном ямбе единичные нарушения цезурного словораздела встречаются чаще, чем в александрийском стихе: такие строки присутствуют у В. Жуковского, А. Пушкина, И. Козлова, А. Полежаева, А. Подолинского, В. Одоевского, А. Майкова и К. Павловой, хотя их никогда не бывает больше $3 \%$. Отклонения, так же как и в 6-стопном ямбе, бывают двух типов: смещение цезурного словораздела на один слог вправо (строки типа Устало со́лнщ̧е, $\|$ жегшее спокойно) ${ }^{5}$ и исчезновение словораздела в окрестности цезуры (Нет муки сла|l:дострастней и больней). У Жуковского, Пушкина, Подолинского и Козлова встречается только первый тип, в то время как у остальных поэтов - оба.

Начиная со второй половины XIX в. цезурный 5-стопный ямб выходит из употребления; по данным Дж. Бейли у поэтов 1880-1922 гг. словораздел в позиции цезуры встречается лишь в 60-80\% строк [Бейли 2004: 211-219], по данным М. Л. Гаспарова у советских поэтов - не чаще чем в $50 \%$ строк [Гаспаров 1974:

${ }^{4}$ Автор благодарит Александра Мурашова за сообщение об этом сюжете и последующее его обсуждение.

5 Дж. Бейли называл такое явление передвижной цезурой. 
101-103]). Таким образом, несмотря на то, что 5-стопный ямб уверенно держит позиции самого употребительного классического размера [Гаспаров 1984/2002: 309], его цезурный вариант встречается относительно редко, причем если он все-таки возникает, то это, как правило, означает, что поэт по каким-то причинам выделяет этот размер среди прочих.

На фоне подавляющего преобладания бесцезурного стиха цезурный вариант начинает восприниматься как своего рода экзотика, и поэтому наличие цезуры может подчеркиваться мужской ударной константой. Этот процесс начинается довольно рано - по всей видимости, на рубеже 1890-1900-х гг. Примером такой тенденции могут служить некоторые 5-стопные ямбы К. Бальмонта, ставшие образцом для многих его современников:

Среди песко́в || пустыни вековой,

Безмолвный Сфи́нкс \| царит на фоне ночи,

В лучах Луны́ || гигантской головой

Встает, расте́т, - \| глядят, не видя, очи.

$<1897>$

Дальше в этом стихотворении поэт начинает свободно варьировать предцезурные окончания.

В обширном корпусе Бальмонта 5-стопный ямб занимает значительное место (примерно пятую часть от всех стихов), но его цезурные варианты встречаются, напротив, редко. Такой «переходный» тип стиха, несмотря на то, что поэт использует его только на рубеже веков, не остается незамеченным - это показывают некоторые стихи старших символистов и младших современников Бальмонта. Его предшественниками были, по всей видимости, Н. Минский («Во сне и наяву», 1879) и Д. Мережковский («Герой, певец, отрадны ваши слезы...», 1883), похожие примеры обнаруживаются в 5-стопных ямбах Ю. Балтрушайтиса («Вся мысль моя - тоска по тайне звездной...», 1909, «В вечерней мгле теряется земля...», <1911>), Вяч. Иванова («Отречение», <1902>, «Воспоминание», <1902>, «Любовь», <1902>), И. Бунина («Ненастный день. Дорога прихотливо...», 1894, «За все Тебя, Господь, благодарю!..» <1901>, «Светло, как днем, и тень за нами бродит...», 1901, «С острогой», <1905>). Среди младших поэтов ту же тенденцию можно видеть у Блока рубежа 1890-1900-х гг. ${ }^{6}$, а также у В. Ходасевича, сохранившего ее на всем протяжении творческой деятельности («Старинные друзья», 1907, «Со слабых век сгоняя смутный сон...», 1914, «Порок и смерть», 1921), хотя иногда он использовал и обычную слабую цезуру («Уединение», 1915), и бесцезурный стих. Среди всех этих поэтов цезурный размер чаще всего использует Вяч. Иванов, причем он появляется у него во все периоды его долгой поэтической

${ }^{6}$ Среди позднейших 5-стопных ямбов Блока лишь два используют цезуру - «О доблестях, о подвигах, о славе...» (1908), «Миры летят. Года летят. Пустая...» (1912), но в обоих случаях она слабая, без сколько-нибудь выраженной «бальмонтовской» тенденции. 
карьеры, - почти всегда у него наблюдается либо цезура «бальмонтовского» типа, с тяготением к мужской, либо слабая цезура в духе XIX в. Исключительно слабой цезурой пользуется Брюсов, у которого, впрочем, гораздо больше бесцезурного стиха.

В отдельных стихотворениях Бунин, чье скептическое отношение к модернистской поэзии хорошо известно, идет даже дальше модернистов и использует сильную мужскую цезуру, причем последовательное ее соблюдение воспринимается, по всей видимости, как способ придать привычному размеру привкус экзотики:

В шелках песко́в || лишь сизые полыни

Растит Алла́х || для кочевых отар,

И небеса́ || здесь несказанно сини,

И солнце в ни́х — $\|$ как адский огнь, Сакар.

$$
\text { «Ковсерь», <1905> }
$$

Несколько дальше идет И. Анненский, воспринимающий мужскую цезуру как характерную черту обновленного Бальмонтом пятистопника. У Анненского систематическое использование сильной мужской цезуры дополнительно подчеркивается синтаксисом - так же, как в 6-стопном ямбе (таких стихотворений у него порядка 25, то есть это отнюдь не случайность):

Среди миро́в, || в мерцании светил

Одной Звезды́ $\|$ я повторяю имя...

Не потому́, || чтоб я Ее любил,

А потому́, $\|$ что я томлюсь с другими.

1909

Я - слабый сы́н || больного поколенья

И не пойду́ || искать альпийских роз,

Ни ропот во́лн, || ни рокот ранних гроз

Мне не даду́т || отрадного волненья.

$$
\text { «Ego», } 1909
$$

Строго говоря, почти все 5-стопные ямбы Анненского написаны таким образом, в том числе и пародия на Бальмонта «Моя душа эбеновый гобой...». Вдохновившее эту пародию стихотворение «Моя душа оазис голубой...» было построено несколько иначе: начало стихотворения выдерживает мужскую цезуру, которая затем ослабляется, а в последних строках вовсе исчезает. Анненский усиливает тенденцию оригинала: цезурный словораздел выдерживается везде, и почти везде он мужскойㄱ:

Моя душа́ || оазис голубой,

7 Эхом этого стихотворения Бальмонта можно считать текст раннего Н. Тихонова «Моя душа в бездумности озер...» (1913-1919?), где происходит возвращение к цезурной стратегии старшего 
Средь бледных ду́ш \| других людей, бессильных.

Роскошный со́н || ниспослан мне судьбой,

Среди пусты́нь, || томительных и пыльных.

Везде пески́. || Свистя, бежит самум.

Лазурь небе́с || укрылася в туманы.

Но слышу я́ || желанный звон и шум,

Ко мне сквозь мглу́ || подходят караваны.

Веселые, || раскинулись на миг,

Пришли, ушли́, || до нового свиданья,

В своей душе́ || лелеют мой двойник,

Моей мечты || воздушной очертанья.

И вновь оди́н, || я вновь живу собой,

Мне снится ра||?дость вечно молодая.

Моя душа́ || оазис голубой,

Мои мечты́ || цветут, не отцветая.

Моя душа́ || эбеновый гобой,

И пусть я ни́ц || упал перед кумиром,

С тобой, дитя́, || как с медною трубой,

Мы всё ж, пойми́, || разъяты целым миром.

О будем же || скорей одним вампиром,

Ты мною бу́дь, || я сделаюсь тобой,

Чтоб демонов || у Яра тешить пиром,

Будь ложкой мне́, || а я тебе губой...

Пусть демоны || измаялись в холере,

Твоя коза́ || с тобою, мой Валерий,

А Пантео́н || открыл над нами зонт,

Душистый зо́нт || из шапок волькамерий.

Постой... Но ло́жь - \| гобой, и призрак - горизонт.

Нет ничего́ || нигде - один Бальмонт.

поэта: мужская цезура в начале, затем ее ослабление и частичное устранение в конце. Тем самым, можно говорить о том, что эксперименты с цезурой у Бальмонта не остались незамеченными. 
В тех случаях, когда у Анненского сильная мужская цезура все-таки не соблюдается, имеет место слабая цезура, причем в некоторых строках она дополнительно ослабляется за счет более плотных синтаксических связей между второй и третьей стопой или, напротив, усиливается, чтобы создать впечатление ритмического курсива. Особенно показательно в этом отношении стихотворение «Кошмары», построенное на тонкой игре с различными типами цезуры:

«Вы ждете? || Вы в волненьи? Это бред.

Вы отворять || ему идете? Нет!

Поймите: к вам || стучится сумасшедший,

Бог знает где \| и с кем всю ночь проведший,

Оборванный, || и речь его дика,

И камешков || полна его рука;

$<\ldots>$

Послушайте!.. || Я только вас пугал:

Тот далеко, || он умер... Я солгал.

И жалобы, || и шепоты, и стуки, -

Все это «ше||?лест крови», голос муки... $<1900-е$ годbl>

В этом отрывке мужское предцезурное окончание используется в случаях, когда нужно передать аффектацию, овладевающую персонажем: Поймите: к вам..., Бог знаem где... и т. п. При этом эти строки могут быть прочитаны и без подчеркнутой цезуры: синтаксическая связь между полустишиями в них довольно сильная, заставляющая читать их слитно. И все же то, что словораздел удерживается на протяжении всего стихотворения, заставляет внимательнее к ним приглядеться. Строку, где цезурное членение нарушается (Все это «шелест крови»...), стоит читать как ритмический курсив она содержит скрытую отсылку к повести «После смерти (Клара Милич)» Тургенева.

Такой же тип стиха предпочитают и М. Кузмин и М. Волошин, представители младшего по сравнению с Анненским и Бальмонтом поколения. Они довольно часто прибегают к цезурному пятистопнику (у М. Кузмина 14 из 104 всех 5-стопных ямбов, у Волошина - 25 из 54), хотя у них использование этого размера ограничено рубежом 1900-1910-х гг.

У Кузмина граница между размерами с сильной цезурой и слабой выражена более отчетливо: если у Бальмонта и его современников можно говорить о тенденции к сильной мужской цезуре, то в его случае нужно говорить о двух группах текстов - с сильной мужской цезурой и с традиционной слабой:

О тихий кра́й, || опять стремлюсь мечтою сильная м.и.

К твоим луга́м $\|$ и дремлющим лесам,

Где я броди́л, || ласкаемый тоскою,

Внимал лесны́м $\|$ и смутным голосам...

М. Кузмин, «О тихий край, опять стремлюсь мечтою...», 1908-1909 
И, ду́маю, || туманится их взгляд:

«Ах, ю́ноши, || когда б пришел к вам опыт.

Ты, мо́лодость, || вернешься ль к нам назад?»

Наве́ки уж || утрачен резвый топот

Веселых но́г, || не заблистает глаз,

Любовью по́лн, $\|$ и тщетен грустный ропот...

$$
\text { М. Кузмин, «Стрельы», <1909> }
$$

д.ц.

д.ц.

д.ц.

д.ц.

М.ц.

М.Ц.

В 85 строках последнего текста $28 \%$ дактилических словоразделов и $72 \%$ мужских, что довольно близко к показателям XIX в. Однако на этом фоне можно заметить разного рода вольности - отсечение проклитики цезурным словоразделом (Кoторой, без || любви, бежал я сам?) и смещение позиции словораздела на слог вправо (Где спят признань |'я, девичий испуг!), которые напоминают ритмический курсив.

У Волошина в целом наблюдается либо тяготение к сильной мужской цезуре с единичными отклонениями (более уверенная тенденция, чем у Бальмонта), либо избегание цезурного словораздела после второй стопы. Причем почти всегда сильная цезура наблюдается в сонетах, которые, в свою очередь, объединены в венки: цезура, по всей видимости, позволяет поэту делать эту предельно твердую форму еще более твердой. В цикле сонетов «Киммерийские сумерки» (1907-1909) и более позднем венке «Lunaria» (1913) мужская цезура присутствует лишь как тенденция, только в некоторых стихотворениях, зато в венке «Corona Astralis» (1909) она употребляется в каждом:

Кому земля́ - || священный край изгнанья,

Того просто́р || полей не веселит,

Но каждый ша́г, || но каждый миг таит

Иных миро́в || в себе напоминанья.

В этом же русле движется И. Северянин - великий новатор цезурного стиха, который в 5-стопном ямбе выступает, напротив, почти консерватором. Размеры с подчеркнутой мужской цезурой приобретают у него оттенок стилизации (прежде всего любимого им И. Мятлева) и допускают отдельные отступления в согласии с развитием темы. Наиболее известное стихотворение в этом духе может быть названо манифестом поэтического стилизаторства ${ }^{8}$ :

В те времена́, || когда роились грезы

В сердцах люде́й, || прозрачны и ясны,

Как хороши́, || как свежи были розы

Моей любви́, || и славы, и весны!..

${ }^{8}$ Интересно, что молодой Г. Иванов, находящийся под сильным впечатлением от творчества Северянина, вслед за ним также пользуется цезурным 5-стопником, всегда исключительно со слабой цезурой. 
$<\ldots>$

Прошли лета́, || и всюду льются слёзы...

Нет ни страны́, || ни тех, кто жил в стране...

Как хороши́, || как свежи были розы

Воспомина́ $\|$ 'ний о минувшем дне! *

И. Северянин, «Классические розы», 1925

Нужно заметить, что цезурный вариант размера в XX в. часто употребляться в стилизациях (Гаспаров 2002: 239), причем и размеры с сильной цезурой, и размеры со слабой одинаково отсылают к поэтической классике XIX в. В силу этого поэты могут «маскировать» цезурный словораздел - так, что опознать его может только ценитель классического стиха:

Ты белый сти́х || в обычай ввел отныне

Для дру́жеских || посланий. В добрый час,

Далекий дру́г, || но смутно близкий часто

Моей душе́, || как Иппокрены звон

Сквозь голоса́ || толпы любимцу Муз

Издалека́ || ежеминутно внятен...

Вяч. Иванов, «Послание на Кавказ», 1912
М.ц.

д.ц.

М.ц.

М.ц.

М.Ц.

М.Ц.

Не радуйся || возвышенному дару,

д.ц.

Богатая, || звучащая душа;

д.Ц.

Не верь словам, || что просятся, спеша,

М.ц.

Преодолеть || немых прозрений мару.

М.ц.

Ю. Верховский, <1917>

В стихотворении Иванова цезура не сопровождается ослаблением синтаксических связей в окрестности словораздела, а распределение полустиший (35\% дактилических, 65\% мужских на 140 строк) практически не отличается от речевой модели: таким образом, позиция цезурного словораздела никак не подчеркивается дополнительно и даже скрывается тем, что слова с левой и с правой ее окрестности синтаксически плотно примыкают друг к другу (строки вроде Сквозь голоса ॥ толпьл любимиу Муз).

В младшем поэтическом поколении интерес к цезуре в 5-стопном ямбе в целом ослабевает: у акмеистов изредка используется цезура «бальмонтовского» типа иногда в более, иногда в менее регулярном виде. Явный интерес к цезурному ямбу испытывает только М. Цветаева (18 текстов) и в какой-то мере О. Мандельштам (7 текстов). У них в отдельную группу выделяются стихотворения, где мужская цезура доминирует, но допускает разного рода отступления - такие же, как у И. Северянина, с которым они в этом сходятся: 
Андрей Шенье' $\|$ взошел на эшафот, А я живу́- $\|$ и это страшный грех.

Есть времена́ - $\|$ железные - для всех.

И не певе́ц, || кто в порохе - поет.

И не оте́ц, $\|$ кто с сына у ворот

Дрожа срыва||'ет воинский доспех.

Есть времена́, || где солнце - смертный грех.

Не челове́к - $\|$ кто в наши дни живет.

М. Цветаева, «Андрей Шенье», 1918

Огромный па́рк. || Вокзала шар стеклянный.

Железный ми́р || опять заворожен.

На звучный пи́р || в элизиум туманный

Торже́ственно || уносится вагон:

Павлиний кри́к $\|$ и рокот фортепьянный.

Я опозда́л. || Мне страшно. Это - сон.

О. Мандельштам, «Кониерт на вокзале», 1921

В поэзии эмиграции интерес к цезуре, напротив, повышается - видимо, в последний раз в русском стихосложении. Причиной этого можно считать ту же ориентацию на классические образцы (пусть даже с привкусом мифологизации), о которой шла речь выше. При этом интерес к цезуре заметен в большей мере у поэтов «второго» ряда: среди «европейских» эмигрантов к ней регулярно прибегает Б. Божнев и В. Набоков, особой популярностью она пользуется у «китайской» части русской эмиграции - у А. Несмелова и В. Перелешина, перед которыми, видимо, более остро стояла задача сохранения классической метрики. У всех этих поэтов преобладает слабая цезура, часто с единичными нарушениями словораздела, а некоторые стихотворения демонстрируют «бальмонтовскую» тенденцию к мужской:

К глубокому $\|$ столбу привязан пруд...

Свисает цепь, || своих длиннее звеньев...

И две ступе||'ни черные ведут,

Нет, лишь одна - $\|$ в чистилище гниенья.

Б. Божнев, <1939>

А горизонт - $\|$ он выгоренно-дымчат -

Как ветхих ряс $\|$ тепло шуршащий шелк...

Мой взгляд грустнел, || в нем растворялось «нынче»,

К далекому \| парящий дух ушел.

А. Несмелов, <1922> 
Во второй половине XX в. цезурный 5-стопный ямб фактически исчезает. Им немного пользуется молодой Бродский («Воротишься на родину. Ну что ж...», 1961), тяготеющий к мужской цезуре, и Аронзон («Троллейбусы уходят в темноту...», <1962>), чаще всего предпочитающий слабую цезуру. Но даже у них количество таких стихотворений не доходит до десяти, у других же поэтов (Б. Ахмадуллиной, О. Чухонцева, А. Еременко, М. Айзенберга) редко превышает два-три образца с заметным количеством отступлений.

Совсем другая история у экспериментов с «неканонической» цезурой, которые продолжились спустя почти два столетия после ломоносовского перевода из Горация. Известно одно стихотворение Черубины де Габриак, в котором вместо привычного цезурного членения $2+3$ использовано членение $3+2$ [Гаспаров 2001: 82-83]:

Он долго говори́л, || и вдруг умолк.

Мерцали нам со сте́н $\|$ сияньем бледным

Инфант Вела́скеса \| тяжелый шелк

И русый Тициа́н $\|$ с отливом медным... «Он ульббается», 1910
М.Ц.

М.ц.

д.ц.

М.ц.

Заметим, что цезура в этом стихотворении - слабая, что вкупе с самим выбранным членением, по словам М. Л. Гаспарова, может восприниматься как «знак установки на избранный круг мастеров и знатоков стиха, которые только и смогут расслышать и оценить непривычную новацию» (Там же: 83). Среди более поздней поэзии такие примеры хотя и очень редко, но также встречаются, например в «Стрельнинской элегии» (1960) Иосифа Бродского, где неканоническая позиция цезуры подчеркнута регулярным мужским окончанием в согласии со вкусом эпохи:

Как будто бы зимо́й || в деревне царской является мне те́нь || любви напрасной, и жизнь опять бежи́т || во мгле январской замерзшею волно́й || на брег прекрасный.

Существует несколько стихотворений, в которых цезура после третьей стопы стремится быть дактилической - такой размер фактически совпадает с 4-стопным ямбом с дактилическими наращениями на цезуре. Иногда тяготение к этому размеру присутствует как тенденция, например в некоторых стихотворениях Зинаиды Гиппиус возникает стремление удержать дактилическую цезуру, но на этом фоне случаются отдельные отклонения. Лишь в позднем стихотворении «Дни» (1918) эта тенденция выражена настолько последовательно, что 5-стопный ямб превращается в размер с цезурными наращениями:

К стыду и го́рдости - \| равнопрезрение...

Всему поко́рственный || привет без битвы... 
Тяжеле всех грехо́в - \| Богоубьение,

Жизнь без прокля́тия - $\|$ и без молитвы.

$$
\text { «Что есть грех?..»,1902 }
$$

Она шерша́вая, || она колючая,

Она холо́дная, || она змея.

Меня изра́нила $\|$ противно-жгучая

Ее коле́нчата||'я чешуя.

$$
\text { «Она», } 1905
$$

Все дни изло́маны, || как преступлением,

Седого Вре́мени $\|$ заржавел ход.

И тело ско́вано $\|$ оцепенением,

И сердце сда́влено, \| и кровь - как лед.

$$
\text { «Дни», } 1918
$$

Подобные же «переходные» формы встречаются и у современников Гиппиус, например у Валерия Брюсова, который может более резко нарушать возникшую было дактилическую тенденцию:

В наемной ко́мнате $\|$ все ранит сердце:

И рама зе́ркала, $\|$ и стульев стиль, Зачем-то со стены́ $\|$ глядящий Герцен, И не смете́нная $\|$ с комода пыль. «В наемной комнате», <1912>

По всей видимости, первые два из этих стихотворений были источниками для того полномасштабного пересмотра репертуара цезурных размеров, который проделал Игорь Северянин. В то же время позднее стихотворение Гиппиус «Дни» отражает уже следующую стадию развития цезуры - когда цезурные эффекты становятся законной частью новой русской метрики.

Наконец, последнее, но едва ли не самое важное - размеры на основе 5-стопного ямба, которые допускают амбивалентную интерпретацию. Такие размеры, по всей видимости, были одним из основных источников для развития неклассической метрики - дольников, некоторые ритмические формы которых совпадают с силлабо-тоническими размерами. Характерный пример - стихотворение Осипа Мандельштама «Дано мне тело...» (1909), которое формально укладывается в 5-стопный ямб. В нем нет канонической цезуры после второй стопы и даже намека на нее - словораздел в этой позиции намеренно избегается: он всегда смещен либо на один, либо на несколько слогов вправо. В то же время словоразделу после третьей стопы часто предшествуют дактилические окончания (как в примеpax из Гиппиус), благодаря которым возникает ощущение, что строка должна делиться на две части; они соблюдаются нерегулярно, но достаточно часто, чтобы 
остальные строки прочитывались в этом же русле. В итоге 5-стопный ямб начинает звучать как 4-иктный дольник с вариациями в окрестности цезуры:

Дано́ мне те́ло - $\|$ что мне де́лать с ни́м, ж.ц.

Таки́м еди́ным $\|$ и таки́м мои́м? ж.ц.

За ра́дость ти́хую \| дыша́ть и жи́ть д.ц.

Кого́, скажи́те, || мне благодари́ть? ж.ц.

Я и садо́вник, || я же и цвето́к, ж.ц.

В темни́це ми́ра || я не одино́к. ж.ц.

На сте́кла ве́чности || уже́ легло́ д.ц.

Моé дыха́ние, || мое́ тепло́. д.ц.

Запечатле́ется || на не́м узо́р, д.ц.

Неузнава́емый || с неда́вних по́р. д.ц.

Пуска́й мгнове́ния || стека́ет му́ть - д.ц.

Узо́ра ми́лого || не зачеркну́ть. д.ц.

Таким образом, размер этого стихотворения можно считать одновременно и 5-стопным ямбом, и 4-иктным дольником с цезурными эффектами ${ }^{9}$. Подобные «амбивалентные» размеры представляют особый интерес в качестве источников для неклассической метрики, начинающей активно развиваться уже в следующую эпоху — в 1910-е гг.

\section{Литература}

Бейли Дж. Избранные статьи по русскому литературному стиху. М.: Языки славянских культур, 2004.

Гаспаров М.Л. Современный русский стих. М.: Наука, 1974.

Гаспаров М.Л. Русский стих начала ХХ в. в комментариях. 2-е изд., доп. М.: Фортуна Лимитед, 2001.

Гаспаров М.Л. Очерк истории русского стиха. Метрика. Ритмика. Рифма. Строфика. 2-е изд., доп. М.: Фортуна Лимитед, 2002.

Гаспаров М.Л. Очерк истории европейского стиха. 2-е изд., доп. М.: Фортуна Лимитед, 2003.

${ }^{9}$ В качестве параллели к этому размеру можно привести стихи Бальмонта, написанные, как обозначал это сам поэт, «прерывистыми строками», - тактовики 1900-х гг., также полученные на основе 5-стопного ямба, но путем прицельного расшатывания исходного ямбического ритма. Подробнее см.: [Полилова 2017]. 
Жирмунский В.М. Теория стиха. Л.: Советский писатель, 1975.

Полилова В. О неклассическом стихе Бальмонта: ритмическая структура «прерывистых строк» // Зборник Матице српске за славистику. 2017. Књ. 92. С. 731746.

Поэты 1790-1810-х гг. / вступ. ст. и сост. Ю.М. Лотмана; под ред. М.Г. Альтшуллера. Л.: Советский писатель, 1971.

Тарановский К. Русские двусложные размеры // Тарановский К. Русские двусложные размеры. Статьи о стихе / пер. с серб. В. В. Сонькина. М.: Языки славянских культур, 2010. С. 13-363.

Тредиаковский В.К. Способ к сложению российских стихов, против выданного в 1735 годе исправленный и дополненный // Тредиаковский В. К. Сочинения и переводы как стихами, так и прозою. Литературные памятники. СПб.: Наука, 2009. C. 69-99.

Шапир М. И. Metrum et rhythmus sub specie semioticae // Шапир М.И. Universum versus: Язык - стих - смысл в русской поэзии XVIII-XX веков. М.: Языки славянских культур, 2000. С. 91-130.

Wagenknecht Ch. Deutsche Metrik. Eine historische Einführung. 5. Aufl. München: Verlag C.H. Beck, 2007.

\author{
K. M. Korchagin \\ Vinogradov Russian Language Institute \\ of the Russian Academy of Sciences \\ (Russia, Moscow) \\ stivendedal@gmail.com
}

\title{
CAESURA IN THE RUSSIAN IAMBIC PENTAMETER AND ITS IMPACT ON THE RHYTHMIC EVOLUTION OF THIS METER
}

The present paper regards iambic pentameter which is one the most frequent meters in Russian poetry and one of the best examined. Its rhythmic patterns had been studied by Kirill Taranovsky with Mikhail Gasparov in their notably works on Russian versification. Nevertheless, a number of rhythmic relevant facts had been neglected in these studies, especially an issue of caesura. In popular handbooks, iambic pentameter is still regarded as caesured meter although most of the examples of this meter definitely demonstrate lack of caesura. Despite that, the history of caesura in Russian iambic pentameter can be a subject of certain investigation because of its connection to the history of non-traditional modernist metrics. In the first iambic pentameters, the caesura after the second foot preceded by fixed accent was applied by Vasiliy Trediakovsky and Aleksander Sumarokov. This interpretation of caesura was quite different from such in the iambic hexameter where these poets always implemented caesura without a fixed accent. Quite soon, the iambic pentameter was vanishing from the repertoire of the epoch and returned at the end of the century. In the late 1810 s, there was a dispute on caesura in the iambic pentameter 
between Vasiliy Zhukovskiy and Aleksandr Pushkin: the elder poet in his translation of Johann Jakob Hebel's Die Vergänglichkeit showed implementation of un-caesured verse in narrative poetry, and then Pushkin wrote a quite malign epigram on this Zhukovsky's oeuvre in order to return to caesured verse in Boris Godunov several years later and, afterwards, to decline this verse in Domik v Kolomne. After several decades, at the early finde-siècle time, Konstatin Balmont partially returned to caesured verse in his attempts to renovate traditional Russian metrics. In his pentameters, there was no constant caesura as in Pushkin's Boris Godunov; instead of this, there was a bias to caesura keeping a strong resemblance to the old caesured pentameter. This bias was repeated by many poets from the early 1900 s to the late 1910 s where attempts to renovate the old metrics were replaced by attempts to invent the new ones. This kind of iambic pentameter was implemented by Vyacheslav Ivanov, Ivan Bunin, Zinaida Gippius, Vladislav Khodasevich, Nikolay Tikhonov and other poets. A significant poem demonstrating how these two different kinds of metrics replace each other is Osip Mandelshtam's "Dano mne telo..." (1909). The verse of this poem can be interpreted both as iambic pentameter and as four-accented dolnik (strict stress meter in terms of English versification). This ambiguity is an effect of lacking routine caesura after the second foot followed by the frequent paroxytonal and proparoxytonal accents after the third. All of these make an impression of a symmetric two-segmented and two-accented verse pattern. One can say this poem was a summit in the history of caesured pentameter: in the following 20th century poetry, caesured iambic pentameter was used only by the poets who wanted to stylize 19 th century poetry. Unlike the un-caesured iambic pentameter, the caesured iambic pentameter was one of the rarest meters in the 20th century Russian poetry.

Key words: metrics, theory of verse, iambic pentameter, caesura, the evolution of Russian verse, poetic corpus, Russian National Corpus

\section{References}

Bailey J. Izbrannye stat'i po russkomu literaturnomu stikhu [Collected Works on the Russian Literary Verse]. Moscow, Yazyki slavyanskikh kul'tur Publ., 2004. (In Russ.)

Gasparov M. L. Ocherk istorii evropeiskogo stikha [A History of European Versification]. Moscow, Fortuna Limited Publ., 2003 (In Russ.)

Gasparov M.L. Ocherk istorii russkogo stikha. Metrika. Ritmika. Rifma. Strofika [History of the Russian Verse Outline]. Moscow, Fortuna Limited Publ., 2002. (In Russ.)

Gasparov M.L. Russkii stikh nachala XX v. v kommentariyakh [Early 20th Century Russian Verse with Notices]. Moscow, Fortuna Limited Publ., 2001. (In Russ.)

Gasparov M. L. Sovremennyi russkii stikh [Modern Russian Verse]. Moscow, Nauka Publ., 1974. (In Russ.)

Poety 1790-1810-kh gg. [1790s—1810s poets]. Leningrad, Sovetskii pisatel' Publ., 1971. (In Russ.)

Polilova V. O neklassicheskom stikhe Bal'monta: ritmicheskaya struktura «preryvistykh strok» [On the Balmont's Non-Classic Verse in "preryvistye stroki"]. Zbornik Matitse srpske za slavistiku, 2017, iss. 92, pp. 731-746. (In Russ.) 
Shapir M. I. Metrum et rhythmus sub specie semioticae. In: Shapir M. I. Universum versus: Yazyk - stikh - smysl v russkoi poezii XVIII—XX vekov [Universum versus: Language - Verse - Meaning in $18^{\text {th }}$ - $20^{\text {th }}$ century Russian Poetry]. Moscow, Yazyki slavyanskikh kul'tur Publ., 2000, pp. 91-130. (In Russ.)

Taranovskii K. [Russian Binary Meters]. Taranovskii K. Russkie dvuslozhnye razmery. Stat'i o stikhe [Russian Binary Meters. Works on Verse]. Moscow, Yazyki slavyanskikh kul'tur Publ., 2010, pp. 13-363. (In Russ.)

Trediakovskii V.K. [A New and Brief Way for Composing of Russian Verses]. Trediakovskii V.K. Sochineniya i perevody kak stikhami, tak i prozoyu [Oeuvres and Translations in Verse and Prose]. Saint Petersburg, Nauka Publ., 2009, pp. 69-99. (In Russ.)

Wagenknecht Ch. Deutsche Metrik. Eine historische Einführung. München, Verlag C. H. Beck, 2007.

Zhirmunskii V. M. Teoriya stikha [Verse Theory]. Leningrad, Sovetskii pisatel' Publ., 1975. (In Russ.) 